\title{
SPATIAL SIMULATION BASED ON GEOGRAPHIC INFORMATION SYSTEM (GIS) AND CELLULAR AUTOMATA (CA) FOR LAND USE CHANGE MODELING IN SINGARAJA CITY AND ITS SURROUNDING AREA
}

\author{
Nyoman Arto Suprapto ${ }^{1}$, Takahiro Osawa ${ }^{2}$, I Dewa Nyoman Nurweda Putra \\ ${ }^{\mathbf{1}}$ Master Student of Environmental Science, Udayana University, ${ }^{2}$ Master Lecturer of \\ Environmental Science, Udayana University, ${ }^{3}$ Lecturer of Marine and Fisheries \\ Faculty, Udayana University. \\ E-mail : artopraph@gmail.com
}

\begin{abstract}
Singaraja is the second largest city after Denpasar in Bali. The magnitude of the potential of the region both trade and services, agriculture and tourism in Buleleng Regency has given a very broad impact not only on the economy but also the use of land. Economic development in the city of Singaraja cause some effects such as population growth, an increasing number of facilities (social, economic, health, and others), as well as changes in land use.

Changes in land use have a serious impact on the environment in the city of Singaraja. The development of urban areas of Singaraja has given the excesses of increasing the land conversion. Suburb dominated by wetland agriculture has now turned into buildings to meet the needs of shelter, trade and services as well as urban utilities.

This study was conducted by mean to determine how changes in land use from agricultural land into build up land during twelve years (period of 2002 - 2014) and the prediction of land use within the next 12 years (period of 2020 and 2026). Prediction of land use changes will be done using spatial simulation method which is integrating Cellular Automata (CA) and Geographic Information Systems (GIS) which analyzed based on land requirement, the driving variable of land use changes (population and road) and the inhabiting variable of land use change (slope steepness and rivers).
\end{abstract}

Keywords : Land Use Change, Land Use Change Modeling, Celullar Automata, GIS 


\section{Introduction}

Buleleng is the largest regency in Bali with a total area of $1365.88 \mathrm{~km}^{2}$ or $24.25 \%$ of the area of Bali Province. The capital of Buleleng regency is Singaraja city which is composed of 2 districts, namely district of Buleleng and Sukasada. Singaraja is the second largest city in the Bali province after Denpasar. Based on the spatial structure of Bali Province (Bali Provincial Regulation No. 16 of 2009), the urban areas of Singaraja is included as PKW (Center of Regional Activity). Spatial structure mandated by the Bali Provincial Spatial Plan sets the urban areas of Sarbagita as PKN (Center of National Activity) and urban areas of Singaraja as PKW. Thus, the governments of both central and regional level will focus on the development of infrastructure in the urban areas. Enactment of Singaraja urban areas as PKW gives positive and negative impacts of the development because the economic activity will be focused on urban areas. Increased economic activity is one of the positive impacts on the provision of supporting infrastructure. However, land use change is also a threat to the growth and development of the region.

Various methods for modeling land use change have been applied by several researchers. Wijaya (2011) was modeling using Multinomial Logistic Regression (MLR) method. Wu et al. (2006) used regression analysis to model the land use changes in the city of Beijing China and predicting land use 20 years into the future with Markov Chain models. CLUE (Conversion of Land Use and its
Effects) model used by Veldkamp and Sresco (1995) to analyze land use changes in Costa Rica on a local, regional and national. By using a different size scale, this model shows that at local, regional and national levels can produce an opposite effect. Cellular Automata (Markov Chain) in this study is used to determine the location or any area of agricultural land use that could potentially turn into a built up region. Geographic Information System (GIS) used to develop a spatial aspect and constructed the driving variables that affect changes. Some of the variables that led to change in land use are the distance to roads, distance to rivers, distance to settlements, slope, climate, population density and revenue. In this study there are four variables used as factors driving and inhibiting changes in land use such as distance to road, distance to rivers, road network density and slope. Therefore, by combine Cellular Automata method with GIS is expected to give a better answer in modeling the land use change.

This research was conduct to answer several questions, how much change of agriculture land into nonagriculture land in Singaraja City and its surrounding area occurred during the period $2002-2014$ and also how is the prediction of land use changes from agriculture land into nonagriculture land in Singaraja City and its surrounding areas in 2016 and 2026. 


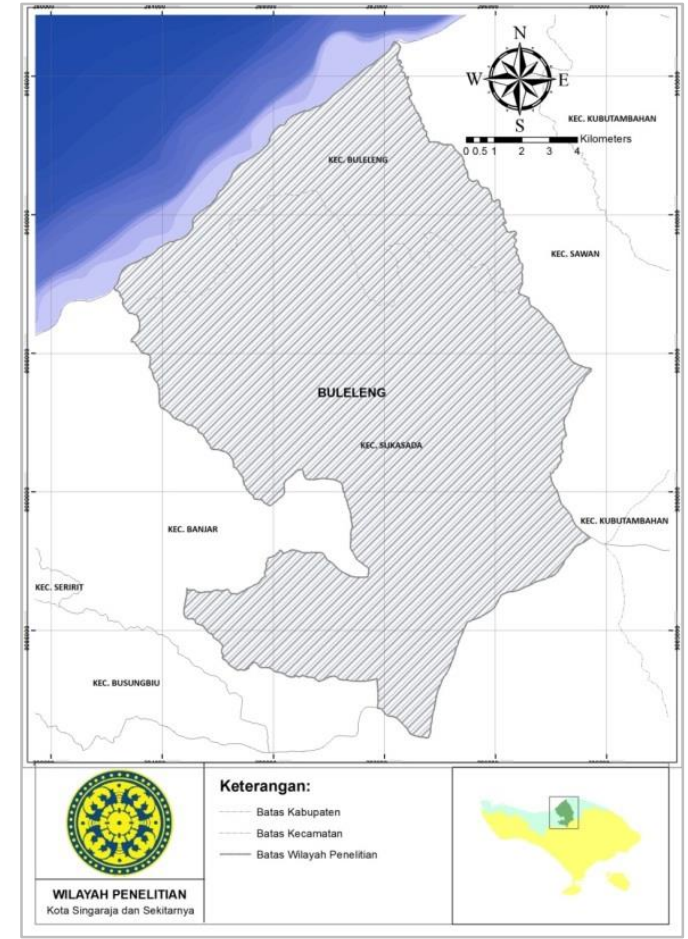

Figure 1. Research Location

\section{Framework of Research}

Land use change caused by many factors, including, the value of land, the potential of the region, infrastructure and population. Population has a very important role in land use. Population is the most dominant variable that determines the changes in land use. Land use change is also determined by the regional development policy, so that the value of land, the potential of the area, infrastructure and population is an important part in the development of the area in the city of Singaraja.

Under Law No. 26 Year 2007 on spatial planning, every region in Indonesia must be set by spatial planning to guide utilization on space. Spatial planning is also needed for the city of Singaraja, especially with the potential for greater flotation area. Lack of analytical methods to determine the allocation of space in the future became a major inhibitor in preparing spatial plans in the city of Singaraja. Spatial planning has been drawn up for Buleleng and also the detailed plans in each districts, it would require a method of evaluation of the spatial plan. In Law 26 of 2007 explained that each 5-year spatial plan product must be evaluated. Land use projection methods are indispensable in the preparation of a detailed plan and evaluation of spatial planning in the future.

Spatial simulation based Geographic Information Systems (GIS) and Cellular Automata (CA) is intended to examine the land use projected system and also projecting land use in the city of Singaraja to find out how is the change of agriculture land use into the built up area to ten years into the future. For more details, research framework of this study is presented in the following diagram.

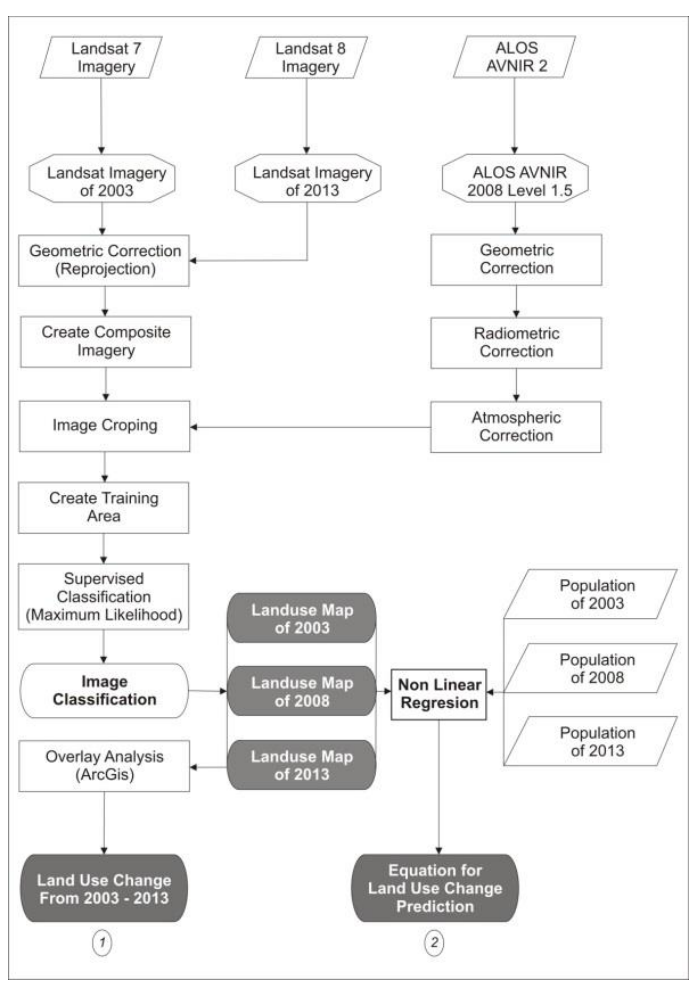




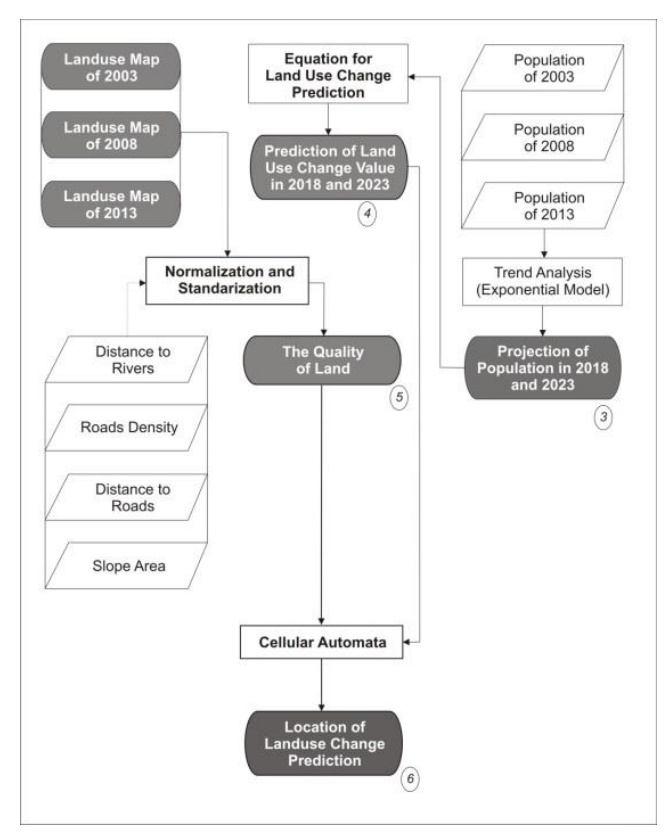

Figure 2. Research Design

\section{Method}

The dynamics of land use changes in this study detected using Landsat ETM+ in 2002 and 2014 with a spatial resolution of $30 \mathrm{mx} 30 \mathrm{~m}$ and ALOS AVNIR2 imagery with a resolution of $10 \mathrm{mx} 10 \mathrm{~m}$. Changes focused on the use of agricultural land into built up land by calculating the amount of land use in each year.

Prediction of land use will be done using spatial simulation method which is integrating the Geographic Information System (GIS) and Cellular Automata (CA). Basic aspects are considered in this spatial simulation is the need of land, land quality and environmental conditions in the vicinity.

Some analysis to be performed in this study are :

\subsection{Land Use Change in period 2002, 2008, and 2014}

Land use change from 2003 to 2013 would be calculated using overlay technique using ArcGIS. By using ArcGIS, an area for agricultural and non-agricultural land can be calculated for each year. Land use change from 2003 to 2008 and from 2008 to 2013 can be calculated by subtracting the amount of nonagricultural or agricultural land in the years thereafter.

LUC = LU $2014-$ LU 2002

Where:

LUC $=$ Land Use Change

LU $2014=$ Land Use in 2014

LU 2002 = Land Use in 2002

\subsection{Prediction of Land Use Change in 2020 and 2026 based on land requirement}

To calculate the projected changes in land use between 2020 and 2026 assuming the land requirement for housing, infrastructure, facilities, trade and services etc. The number of land use in the built up area in 2002, 2008, and 2014 will be analyzed regression to determine how the relationship and the influence of population on land use of built up area. According to Steel at al. (1980) equation of non-linear regression use to calculate the built up area needs in 2018 and 2023 is as follows.

$\mathrm{Y}=\mathrm{a}+\mathrm{b} \ln \mathrm{X}$

Where:

$\mathrm{Y}=$ land use change

$\mathrm{A}=$ constantan

$\mathrm{B}=$ intercept parameter

$\mathrm{X}=$ population 
To calculate the projected land use by 2020 and 2026 then it should use the projected population in 2020 and 2026. Thus, by including the value of the projected population of the above equation will be changed as follows.

$\mathrm{Y}=\mathrm{a}+\mathrm{bln} \mathrm{P}_{\mathrm{t}}$

Where:

$\mathrm{Y}=$ projected land use change in 2020 and 2026

$\mathrm{a}=$ constantan

$\mathrm{b}=$ intercept parameter

$\mathrm{Pt}=$ projected population in 2020 and 2026

\subsection{Prediction of Land Use Change in 2018 and 2023 based on land requirement.}

To calculate the projected population in 2020 and 2026 should be calculated first population growth from 2003 to 2013. By using a model of exponential population growth can then be calculated. After the growth of the population is known, then the calculation of population projections can be done by entering the population growth rate in exponential models. According Kachigan (1986) formula for exponential models are as follows:

$\mathrm{P}_{\mathrm{t}}=\mathrm{a} * \exp \left(\mathrm{b} * \mathrm{P}_{0}\right)$

Where:

$\mathrm{P}_{\mathrm{t}}=$ prediction of the total population in 2020 and 2026

$\mathrm{P}_{0}=$ the total population in 2002 , 2020 and 2026

$\mathrm{a}=$ population growth

$\mathrm{b}=$ intercept parameter

$\exp =\operatorname{exponential}$

\subsection{Mapping Analysis of Land Quality}

The quality of land is an important aspect to be considered in selecting land for a specific use. Land quality can be assessed based on a number of factors or a particular indicator, depending on the type of land use to be commercialized. Soil fertility, availability of irrigation is an important factor to be considered for the use of agricultural land. Location and accessibility, on the other hand, is a more important factor for the use of non-agricultural land.

Indicator of land quality is relative depending on the purpose of assessing the quality of the land. In accordance with the research objectives, quality land assessed based on the accessibility of the land. The assumption used is the higher accessibility of land, more likely to experience changes in land use. This assumption is based on a number of studies on changes in use, particularly change of agricultural land into nonagriculture. The parameter used to assess the accessibility is the slope, distance to roads, density of road network and distance to the river. Analysis and mapping of four parameters is done by using a geographic information system (GIS).

Analysis and mapping of parameter of land quality values produce different unit. Slope parameter using units of percent (\%), distance parameter using unit of meters $(\mathrm{m})$ and the density parameter using units of kilometers per square kilometer $(\mathrm{km} /$ $\mathrm{km}^{2}$ ). Parameter values need to be compared for the further analysis. Equalization is done by means of the 
process of standardization or normalization. The method used to standardize the value of the parameter is a linear transformation using the equation (7) and (8) (Kachigan, 1986).

$$
\begin{aligned}
X^{\prime} & =\frac{X-X_{\min }}{X_{\max }-X_{\min }} \ldots \ldots \ldots(5) 7 \\
X^{\prime} & =\frac{X_{\max }-X}{X_{\max }-X_{\min }} \ldots \ldots \ldots(6) 8
\end{aligned}
$$

Where:

$\mathrm{X}^{\prime}=$ the result of standarisation

$\mathrm{X}=$ parameter value

$X_{\max }=$ parameter of maximum value

$X_{\min }=$ parameter of minimum value

Equation (5) is used to standardize the distance parameter values to the river and the density of the road network. Using equation (5), the value of the parameter will have a range of 0 to 1 Land, in the study area which has the farthest distance from the rivers and the highest density of road network will have a value of 1 . Instead of land closest to the river and lowest road network density, will have a value of 0 .

Equation (6) is used to standardize the value of the parameter distance to roads and slope. Using equation (6), the value of the parameter will have a range of 0 to 1 , but the result is contrast with the use of equation (5). Land which has farthest distance from the road and the steep slopes will have a value of 0 . Instead of land closest to the road and flat slope would have a value of 1 .

\subsection{Prediction of Land Use Change Location}

Location of land use changes predicted by spatial simulation using Cellular Automata (CA). As the name implies, CA contains a number of cells, which has a certain value. Each cell can be changed to follow a certain principle of transition (transition rule). CA consists of four components that interact with each other namely (Liu, 2009):
$\mathbf{U}($ universe $)=$ space dimensional of the cell
$\mathbf{S}$ (state) $=$ circumstance that may achieve by the cell
$\mathbf{N}($ neighborhood $)=$ the number of neighborhood cell that considered to determine the cell value

$\mathbf{T}$ (transition) $=$ a couple of rule used to determine the value of each cell

CA in this study is used to simulate changes in land use from agricultural land into non-agricultural land. The unit used is the simulation cell (pixel) size of $30 \mathrm{mx} 30 \mathrm{~m}$. Each cell has a value of $U$ (universe) and $S$ (state). $U$ value of a cell is the location of the cell indicated by the coordinates $(x, y) . S$ value of a cell is a category of land use. In accordance with the research objectives, then there are only two possible values of $\mathrm{S}$, namely agricultural land and non-agricultural land. Component $\mathrm{T}$ is a rule in the simulation. An example of a rule is "change only applies in one direction, namely from the state agricultural land into non-agricultural land". Other 
example of the rule is "the total number of cells that can be changed during the simulation process is 1500 cells".

In this study CA algorithm used to simulate urban growth in Singaraja City and its surrounding areas. Filter used to simulate urban growth is $3 \times 3$ Moore neighborhood. There are some scenarios used in this study to design the $\mathrm{CA}$ rule and determine the precision. In this study, only use two scenarios for rule to get the highest precision to run the simulation from 2003 to 2023, they are:

\section{Scenario 1:}

1. IF tested pixel under consideration is water, THEN no growth is allowed at this pixel.

2. IF tested pixel under consideration is road, THEN no growth is allowed at this pixel.

3. IF tested pixel under consideration is forest, THEN no growth is allowed at this pixel.

4. IF tested pixel under consideration is settlement (urban), THEN keep this pixel without any change.

5. IF tested pixel under consideration is plantation $\mathrm{OR}$ agriculture AND there are 4 urban pixel in the neighborhood, THEN change center pixel to urban.

\section{Scenario 2:}

1. IF tested pixel under consideration is water, THEN no growth is allowed at this pixel.
2. IF tested pixel under consideration is road, THEN no growth is allowed at this pixel.

3. IF tested pixel under consideration is forest, THEN no growth is allowed at this pixel.

4. IF tested pixel under consideration is settlement (urban), THEN keep this pixel without any change.

5. IF tested pixel under consideration is plantation $\mathrm{OR}$ agriculture AND there are 3 urban pixel in the neighborhood, THEN change center pixel to urban.

\section{References}

Arsyad, S. 1989. "Konservasi Tanah dan Air". Bogor: IPB Press.

Ashish, D. 2002. "Land-use Classification of Aerial Images Using Artificial Neural Networks". USA: University of Georgia.

As-Syakur, A.R., Osawa, T. and Adnyana, I.W.S. 2010. "Medium Spatial Resolution Satellite Imagery to Estimate Gross Primary Production in an Urban Area". Remote Sensing ISSN 2072-4292: 1496-1507.

Atkinson, P. and A. Tatnall. 1997. "Neural Network in Remote Sensing”. International Journal of Remote Sensing. Vol. 18(4): 699-709.

Bappenas, BPS, UNDP. 2004. "Laporan Pembangunan Manusia Indonesia 2004, Menuju Konsensus Baru Demokrasi dan pembangunan Manusia Di Indonesia”. Bappenas, BPS, UNDP. Jakarta.

Barlowe, R. 1986. "Land Resource Economics". The Economics of Real Estate. Prentice-Hall Inc. New York, 653 p. 
Batty, M and P. A. Longley. 1994. Urban Modelling in Computer Graphic and Geographic Information System Environments. Environment and Planning. Vol.19: 663-688

Berger, T., H. Coucleis, M. S. Manson and C. D. Parker. 2001. "Introduction and Conceptual Overview". Report and review of International Workshop. October 4-7. California USA.

Bockstael, N. R. Costanza, I. Strand, W. Boynton, K. Bell, L. Wainger. 1995. "Ecological Economic Modelling and Valuation of Ecosystems". Ecological Economics. Vol. 14: 143-159.

Briassoulis, Helen. 2000. "Analysis of Land Use Change: Theoritical and Modeling Approaches". West Virginia University.

Chapin, F. Stuart, JR and Kaiser, Edward J. 1995. "Urban and Land Use Planning: Fourth Edition". Chicago: University of Illionis Press.

CSIRO, 2003. "Annual Report". Commonwealth Scientific and Industrial Research Organisation.

ESRI, 2014. "Band Combinations for Landsat 8". Available from:

http://blogs.esri.com/esri/arcgis/2013/07 /24/band-combinations-forlandsat-8/ (accessed : October 24, 2014)

FAO. 1976. "A Framework for Land Evaluation", FOA Soil Bull. Soil Resources Management and Conservation Service Land and Water Development Division. FAO Soil Bulletin No. 52. FAO-UNO, Rome.

Fausett, Laurene. 1994. "Fundamental of Neural Networks". Prentice Hall. New Jersey
Gujarati, Damodar. 1995. "Ekonometrika Dasar". Penerbit Erlangga, Jakarta.

Handoko, I. 2005. "Quantitative Modelling of Systems Dynamics for Natural Resource Management". Bogor: SEAMEO BIOTROP

Hardjowigeno, S. dan Widiatmaka. 2001. "Kesesuaian Lahan dan Perencanaan Tataguna Tanah". Jurusan Tanah, Fakultas Pertanian, Institut Pertanian Bogor. Bogor.

Harris, B. 1966. "Notes on Accessibility", Mimeo, Institute for Environmetal Studies. University of Pennsylvania, Philadelphia.

Ito, S., 2005. "Space Activities of JAXA, Next Generation Earth Observation Satelite System", JAXA (Japan Aerospace Exploration Agency), Japan.

Jensen, J.R. 1986. "Introductory to Digital Image Processing. A. Remote Sensing Perspective". Second Edition. New Jersey : Prentice Hall.

Junaedi, A. 2008. "Konsistensi dan Inkonsistensi Pemanfaatan Ruang dan Implikasinya Terhadap Pelaksanaan Rencana Tata Ruang Wilayah Kabupaten Sumedang”. Tesis. Sekolah Pascasarjana Institut Pertanian Bogor. Bogor.

Kachigan, Sam Kash. 1986. "Statistical Analysis: An Interdiscipinary Introduction to Univariate \& Multivariate Methods". New York: Radius Press.

Kazaz and Charles. 2001. "Contaminated Lands". Presentation of Bill 72 Establishing New Rules for the Protection and Rehabilitation of Coantaminated Lands. Available from: 
http://www.fasken.com/WEB/FMDWEBS

TE.NSF/0/7A37D65E2B09BA1852

56B360077D436/\$File/ENVIROBU LLETIN_FLASH_ANG.PDF?OpenEle ment (accessed: November 7th 2011)

King, A. W., A. R. Johnson, R. V. O'Neill and D. L. De Angelis. 1989. "Using Ecosystem Models to Predict Regional CO2 Exchange Between The Atmosphere and The Terrestrial Biosphere".

Global Biogeochemical Cycles. Vol. 3: 337-361.

Kodoatie, Robert J. 2005. "Pengantar Manajemen Infrastruktur". Yogyakarta: Pustaka Pelajar.

Lambin, E. F., M. Rounsevell and H. Geist. 2000. "Are Current Agricultural Land Use Models Able to Predict Changes in Land Use Intensity?" Agriculture, Ecosystems and Environment. Vol. 1653: 1-11.

Lillesand, T. M., dan R. W. Kiefer. 1997. "Penginderaan Jauh dan Interpretasi Citra". Yogyakarta: Gajah Mada University.

Liu, Yan. 2009. "Modeling Urban Development with Geographical Information System and Cellular Automata". CRC Press.

Mather, A.S. 1986. "Land Use". Longman Group U.K. Limited. New York. 286 p.

Messina, Joseph P. and Stephen J. Walsh. 2001. "Simulating Land Use and Land Cover Dynamics in the Ecuadorian Amazon through Cellular Automata Approaches and an Integrated GIS", Open Meeting of the Human Dimensions of Global Environmental Change Research Community in Rio de Janeiro, Brazil, October 6-8, 2001.
Muller, M. R. and J. Middleton. 1994.

"A Markov Model of Land-use Change Dynamics in the Niagara Region, Ontario, Canada". Landscape Ecology. Vol. 9(2): 161-167

Munibah, Khursatul, Santun R. P. Sitorus, Ernan Rustiadi, Komarsa Ganda Sasmita, Hartrisari. 2008. "Model Hubungan Jumlah Penduduk dengan Luas Lahan Pertanian dan Permukiman". Tanah dan Lingkungan. Vol. 11: 32-40

Murray and Lopez. 2006. "Mortality by Cause for 8 Region of The World: Global Burden of Diseas'e. Available from:

http://www.thelanet.com/journal/vol134 9/iss9062/full/Ilan.349.9061.origi nalreseach.8645.1 (accessed: January 17th 2012).

Nasoetion, L. dan J. Winoto. 1996. "Masalah Alih Fungsi Lahan Pertanian dan Dampaknya Terhadap Keberlangsungan Swasembada Pangan". Didalam: Hermanto (eds), Prosiding Lokakarya Persaingan Dalam Pemanfaatan Sumberdaya Lahan dan Air: pp.64-82. PSE dan Ford Foundation.

Nurrizqi, Erstayudha Hayyu, Suyono. 2013. "Pengaruh Perubahan Penggunaan Lahan Terhadap Perubahan Debit Puncak Banjir di Sub Das Brantas Hulu". Yogyakarta: Universitas Gadjah Mada.

Pijanowski, B. C., D. G. Brown, B. A. Shellito and G. A. Manik. 2002. "Using Neural Network and GIS to Forecast Land Use Changes: A Land Transformation Model". Computers, Environment and Urban Systems. Vol. 26: 553575. 
Rumelhart, D. E., Hinton, G. E., and Williams, R. J. 1986. "Learning Internal Representations by Error Propagation". In Rumelhart, D. E., McClelland, J. L., and the PDP Research Group, editors, Paralled Distributed Processing. Explorations in the Microstructure of Cognition. Volume 1: Foundations, pages 318-362. The MIT Press, Cambridge, MA.

Rustiadi, Ernan, Sunsun Saefulhakim, Dyah R. Panuju. 2009. "Perencanaan dan Pengembangan Wilayah". Jakarta: Crestpent Press dan YOI.

Siang, J. 2009. "Jaringan Syaraf Tiruan \& Pemrogramannya Menggunakan Matlab, 2nd edition": Penerbit Andi. Yogyakarta.

Sitanggang, Gokmaria. 2007. "Karakteristik Satelit Penginderaan Jauh Alos Untuk Misi Pemetaan dan Potensi Data Untuk Aplikasi Pemetaan". Majalah Sains dan Teknologi Dirgantara. Vol. 2: 94-107.

Sitorus, S. R. P. 2004. "Pengembangan Sumberdaya Lahan Berkelanjutan. Laboratorium Pengembangan Wilayah". Jurusan Tanah, Fakultas Pertanian, Institut Pertanian Bogor. Bogor

Skapura, D. 1996. "Building Neural Networks". New York: ACM Press.

SNI, 2010. "SNI No. 7645: Klasifikasi Penutupan Lahan". Badan Standarisasi Nasional.

Steel, Robert G.D. and J.H. Torrie. 1980. "Principles and Procedures of Statistics (2nd edition)". McGraw Hill Book Company.
Sugandhy, A. 1999. "Penataan Ruang dalam Pengelolaan Lingkungan Hidup. Jakarta": PT. Gramedia Pustaka Utama

Tayyebi, A., M. R. Delavar, S. Saeedi, J. Amini and H. Alinia.2008. "Monitoring Land Use Change by Multi-temporal Landsat Remote Sensing Imagery". The International Archives of Photogrammetry, Remote Sensing and Spatial Information Sciences. Vol. 37: 1037-1042.

Theobald, D. M. and N.T. Hobbs. 1998. "Forecasting Rural Land Use Change: A Comparison of Regression and Spatial Transition-based Models". Geographical and Environmental Modelling. Vol. 2(1): 65-82.

USGS, 1976. "A Land Use And Land Cover Classification System For Use With Remote Sensor Data": United State Geological Survey.

Vandeveer, Lonnie R. and H. Evan Drummond. 1976. "Estimating The Differential Change in Land Use Associated With Reservoir Construction", Southern Journal of Agricultural Economics. Vol. 08: 169-174.

Veldkamp, A. and E. F. Lambin. 2001. Editorial: "Predicting Land Use Change. Agriculture", Ecosystems and Environment. Vol. 85: 1-6.

Veldkamp, A. and L. O Fresco. 1995. "CLUE-CR: An Integrated Multi-scale Model to Simulate Land Use Change Scenarios in Costa Rica". Ecological Modelling. Vol. 91: 231-248.

Vink, A. P. A. 1975. "Land Use in Advancing Agriculture". Springer Verlaag. New York, $394 \mathrm{p}$ 
Wijaya, C. I. 2011. "Land Use Change Modelling In Siak District , Riau Province, Indonesia Using Multinomial Logistic Regression". Tesis. Sekolah Pascasarjana Institut Pertanian Bogor. Bogor

Wilson, A.G. 1974. "Urban And Regional Models in Geography and Planning". John Wiley \& Sons Ltd., New York.

Wolfram, S. 1984. "Cellular Automata as Models of Complexity", Nature 311: 419-424.

$\mathrm{Wu}$, Qiong. Hong-qin Li, Ru-song Wang, Juergen Paulussen, Yong $\mathrm{He}$, Min Wang, Bi-hui Wang, Zhen Wang. 2006. "Monitoring and Predicting Land Use Change in Beijing Using Remote Sensing". Landscape and Urban Planing. Vol. 78: 322-333.

Yeh and Li, 1998. "Land Use Change Analysis in The Zhujiang Delta of China Using Satellite Remote Sensing, GIS and Stochastic Modeling". Journal of Environmental Management. Vol. 64: 273-284. 